\title{
The difficultiesposed by teaching chemistry in English language: With special reference to health sciences students in Turkish Universities
}

\author{
Tariq Elhadary ${ }^{1 *}$, Ismail A. Elhaty ${ }^{2}$ \\ ${ }^{1}$ Department of Translation and Interpretation, School of Applied Sciences, Istanbul Gelisim University, Istanbul, Turkey. \\ 2 Department of Nutrition and Dietetics, Faculty of Health Sciences, Istanbul Gelisim University, Istanbul.
}

\begin{abstract}
Most students learn in different ways and have different strengths and challenges. Turkish students suffer from some kinds of difficulty in learning chemistry taught in English, whether in school or university. The language of instruction can affect aspects of a student's ability to learn. In this study, the difficulties that Turkish students face in studying chemistry in English are evaluated through a survey of students' opinions at the Department of Nutrition in the University of Gelisim. The results showed that a $52.6 \%$ of students suffer from learning difficulties in the English language, which was reflected in their participation in discussions during the lecture, so a large percentage of them (48.6\%) resorted to taking notes during the lecture in Turkish and a large proportion of them (45.6\%) also believed that the situation would be better if English terms were used alongside Turkish in textbooks. The study claims there is a possibilityof improving students' level in the English language thus improving students' abilities to comprehend chemistry through the applicability of various teaching methods. The study draws heavily on both the Communicative and Natural Approach to deal with communication difficulties in chemistry classes.
\end{abstract}

Keywords

Chemistry; Learning difficulties; Communication; Teaching Methods; Communicative Approach; Comprehensible Input; Turkey

\section{Introduction}

Teaching methods

Good teaching methods stimulate students' interest, motivation to learn, and eagerness for knowledge, as well as motivate them to engage with the teacher.Taking into account individual differences, effective teaching methods help achieve curriculum goals, and conform to the nature of students' mental activity $[1,2]$. The nature of the content forces teachers to choose their teaching methods.It is worthy to note here that there are contents that are mostly theoretical while others are predominantly scientific or experimental.The problem stems when the contents of the study materials have a dense theoretical nature that focuses on pouring information into the minds of the learners[3].It shouldn't go without saying that the advocates of the old school believe theycan only use traditional methods to teach any content, while others support the use of multiplicity of teaching methods for their importance in terms of boosting students' motivation, arousing their interest, and immersing them positively in the class activities.

There is no single method of teaching better than others, as there have been many teaching methods, and there is no consensus among educators as to which method is the best optimal. However, the method of teaching is considered to be the most effective element of the curriculum in achieving educational objectives as it defines the role of both the teacher and the learner in the educational process, and it also specifies the techniques to be followed, the required educational means of communication and the appropriate activities supposed to be undertaken in order to achieve the desired teaching objectives[2, 4].

Teachers should choose the method that is consistent with the topic of their lesson. There are teaching methods based totally on students' activities like the method of solving problems. There are methods based on the activity of the teacher to a large extent such asfrontal teaching method, where the teacher almost always stands at the front of the class and conveys his or her knowledge to the students, while simultaneously controlling their activities during the lesson[3]. Besides, the teacher and students interact through a " to-and-fro " dialog. Moreover, the teacher can also initiate a discussion among students, but always maintains a central position and leads the arguments.There is a teaching method that requires more activities from the teacher and the student, even if the teacher possessesmost of the teaching talking time (TTT) in it which is the method of dialogue and discussion[5].There are individual teaching methodssuch as programmed teaching or computer education, and there are collective teaching methods such as presentation, discussion and solvingproblems, projects, and units[1,2].

Teaching concept

Teaching concept is aprocess of communication between teacher and student, which means moving from one intellectual state to another. The learners grow from moment to moment as a result of their interaction with a range of educational and learning episodes that affect them. Teaching is an individual 
personal system in which the teacher plays a professional role: Teaching[6, 7].

It is a planned system of work that is intended to lead to the education and growth of students in their various aspects. This system includes a set of targeted activities, carried out by both the teacher and the student. This system has three elements: a teacher, a student, a content, and these elements have a dynamic character and include language activities[6]. It is a basic means of communication besides other silent ones, and the purpose of this system is to help students acquire knowledge, skills, values, attitudes and appropriate predispositions[8].

\section{The concept of teaching method}

Teaching method is anapproach taken by the teacher to communicate what was mentioned in the school curriculum (or textbook) such as knowledge, information, skills and activities,to the learner easily and straightforwardly for the sake of facilitating the learnability and acquisition. It is the method or approach that the teacher chooses to help students achieve their behavioral and educational goals which is a set of scientific procedures, practices and activities that the teacher carries out in the classroom teaching a specific lesson aiming at communicating certain information, facts and concepts[1, 2]. It should not go without saying that the teacher can still teach in any way (eclectic approach) that suits the nature of the content to be presented, and the levels of the students and their potentialities. It is worthy to note here that Eclectic approach is a method of teaching that combines various approaches and methodologies to teach a certain content depending on the aims of the lesson and the abilities of the learners. Eclectic approach is based on different teaching methods borrowed and adapted to suit the requirement of the learners[9, 10]. Having touched upon learning difficulties due to language differences, the coming section focuses on the difficulties Turkish students encounter when learning chemistry in English language. The language barrier can pose a serious issue in maintaining smooth uninterrupted communication when students attempt to express their opinions, understanding or even misunderstanding in chemistry classes in English.

\section{Teaching chemistry in English language}

Many students, whether in school or university, suffer from difficulties in studying scientific courses, especially chemistry, where the language of instruction is English. The study attempts to explore the issue from two different perspectives: that of the English language and that of Chemistry as a scientific subject. Sometimes, difficulties of dealing with and grasping chemistry concepts, both basic and advanced, constitutes one of the main reasonsof students'poor performance in university science departments $[11,12]$. Sometimes the difficulties that students face are due to cumulative reasons resulting from the failure to properly understand the basic concepts in chemistry particularly when students start their undergraduate study[13]. Such a student faces great difficulty in understanding the advanced chemistry topics as a result of a poor understanding or lack of comprehending the basic concepts previously mentioned[12]. Other factors that contribute to the poor academic performance in chemistry and consequently cause students' aversion: are the traditional teaching methods used in classroom instruction and the absence of creative dynamic emersion of students in the learning teaching process[11].It should go without saying that the method of presenting the academic scientific content plays a vital role in drawing the attention, maintaining concentration of and arousing interest and appeal in students. Other factors go back to poor competence and lack of expertise of teachers in pre-university stageswherestudents begin to receive basic chemistry concepts $[12,14]$. Therefore, the reasons that might be behind the poor academic performancein chemistry can be summarized as follows:The English language proficiency, the educational environment, the material itself, the student and the last of which is the teacher[15].

Millar has classified the difficulties faced by the learner in general into two parts, the first section is intrinsic difficulties, which are the difficulties related to perception and the educational process[16]. Many studies have been conducted on the causes of difficulty in chemistry, whether at school or university level, and these studies have included basic concepts in important topics such asatoms and molecules, chemical reactions, chemical equilibrium, models and representations of chemical reactions, acids and basis, solutions, combustion, electrochemistry and the mole concept[11].

One of the important factors that contribute to increasing students' alienationand the difficulty in their understanding of chemistry is the difference in the language of instruction at the undergraduate level from that at the school level, as many universities in non-speaking English mediumteach chemistry and scientific majors in English, while the language of study in the school is the native language of the country $[17,18]$. 
In Turkey, all scientific subjects, including chemistry, are taught in Turkish at pre-university stage, as well as at the university,undergraduate through graduate and postgraduate.However, some public universities and many private universities provide the student with the opportunity to choose between studying for a degree in English or Turkish. These universities require students to pass an English proficiency exam if they want to study in English. General chemistry is a basic subject in many scientific disciplines other than the faculties of sciences, such as medicine, veteran, physiotherapy, biomedical, pharmacy, nutrition and some engineering disciplines[19].

There is a clear difference in naming chemical terms and concepts in the Turkish language from the English language.Students accustomed to use the Turkish language in naming chemical elements and compounds, and that requires the student to spend double effort at the university to memorize these terms, concepts and labels in English. If the student mainly suffers from difficulty in understanding chemistry, the problem of language will be another factor that increases the difficulties that this student faces.

This study aims to identify the difficulties that students face in understanding chemistry in general as well as the difficulties they encounter in the English language during the study of chemistry and to identify the reasons behind these difficulties. The study recommendsas well how learning difficulties can be approached by introducing various teaching methods and techniques.

\section{Research Methodology}

\section{Research context}

In this study, the difficulties posed the English language that students face in studying chemistry were studied, and for further investigation a questionnaire was designed that consists of 31 questions. These questions have been divided into groups, the first part of which deals with general information about the student, the second part deals with the difficulties that students faced during their studies at school, and the third part the difficulties students faced during the university, and then the experiential observation students embraced which helped them elicit the reasons behind these difficulties.

Population and sample

A questionnaire was prepared in Turkish and another in English using the Google form website, and the link was sent to students through the university email, leaving them free to choose the language of the questionnaire. This questionnaire was distributed to students of general chemistry in the Department of Nutrition and Dietetics at the College of Health Sciences, GelisimUniversity. Most students are first and second year students, with a limited number of students in senior years, as the university system allows students to retake subjects in which theyscored low grades. Females constitute the majority of the population of the department, as there are only a few numbers of males.

Data analysis

After collecting the responses from the students, the questions were sorted by type and the options were given a numerical value for easy analysis. These responses were analyzed using SPSS Version 25 software.Frequency analysis, percentage analysis and descriptive statistics were used to get inferences.

\section{Results and Discussion}

\section{Learning difficulties}

This work aims to examine the difficulties that Turkish speaking students face while studying chemistry in English at the undergraduate level. The participants' responses are shown in Tables 1 -4.The study was conducted on 65students of the Nutrition Department of the Faculty of Health Sciences at IstanbulGelisim University, where the study included (4.61\%) male students, and $(95.39 \%)$ female students.Most of students are the first $(43.1 \%)$ and second year $(40.0 \%)$ and the study shows that the majority of students $(87.7 \%)$ studied chemistry at the school stage in Turkish and few of them studied it in English (12.3\%) as shown in Figures 1 and 2 respectively. The study also shows that the number of students who studied in public schools $(50.8 \%)$ is slightly greater than those who studied in private schools (49.2\%) as shown in Figure 3, and this does not represent the reality in Turkey, as the majority students study in public schools $(91.2 \%)[20]$.The reason may be that, Istanbul Gelisim University is a private university, that is why the percentage of Turkish students who studied in private schools is considerably high. Students who want to complete their studies at the university must sit a language-level assessment test, and whoever successfully passes it is enrolled in the university to complete their studies. Those who cannot pass the exam enrollin a compulsory English language course and then retake the exam at a later date. 


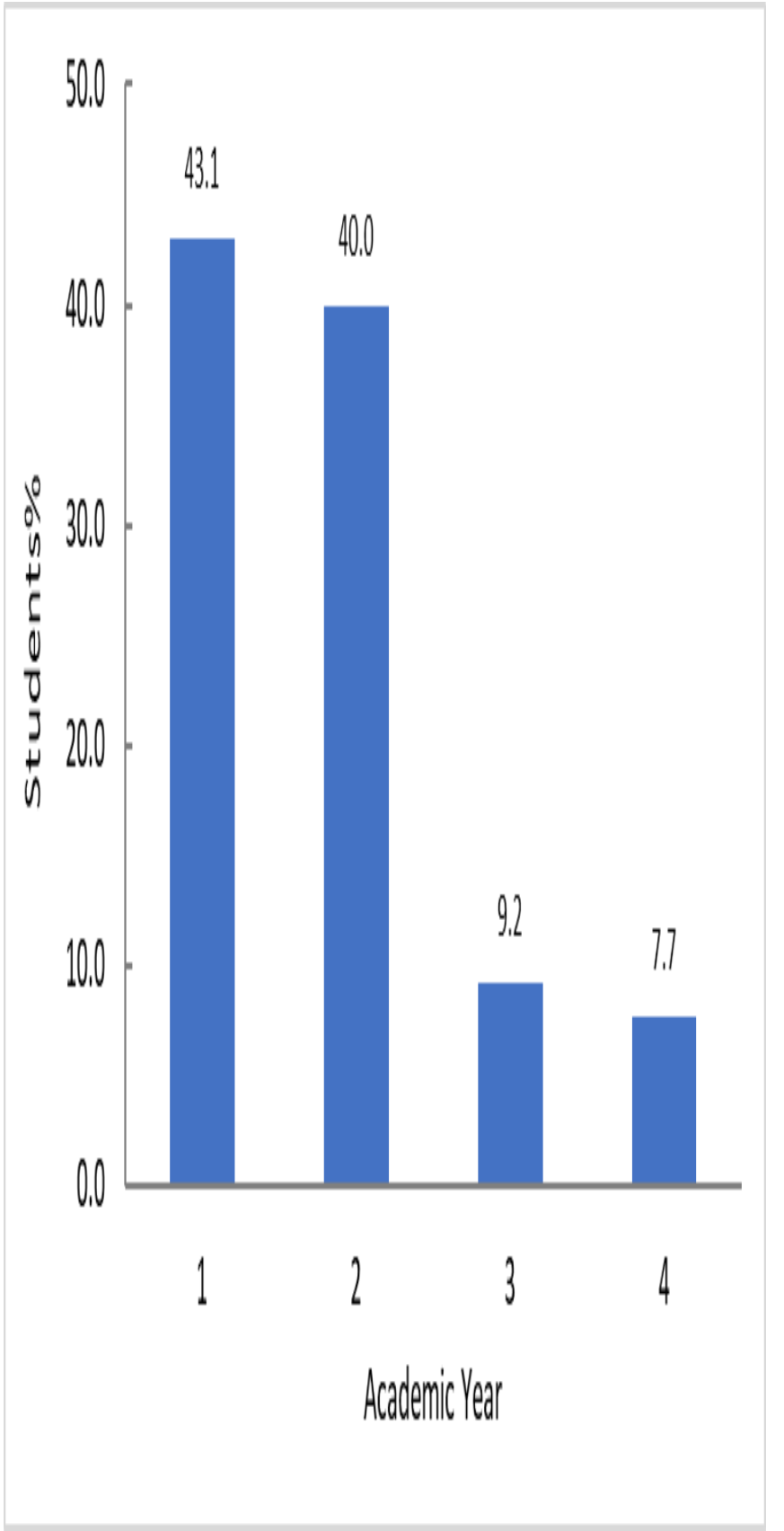

Figure 1. Number of the students per the academic year.

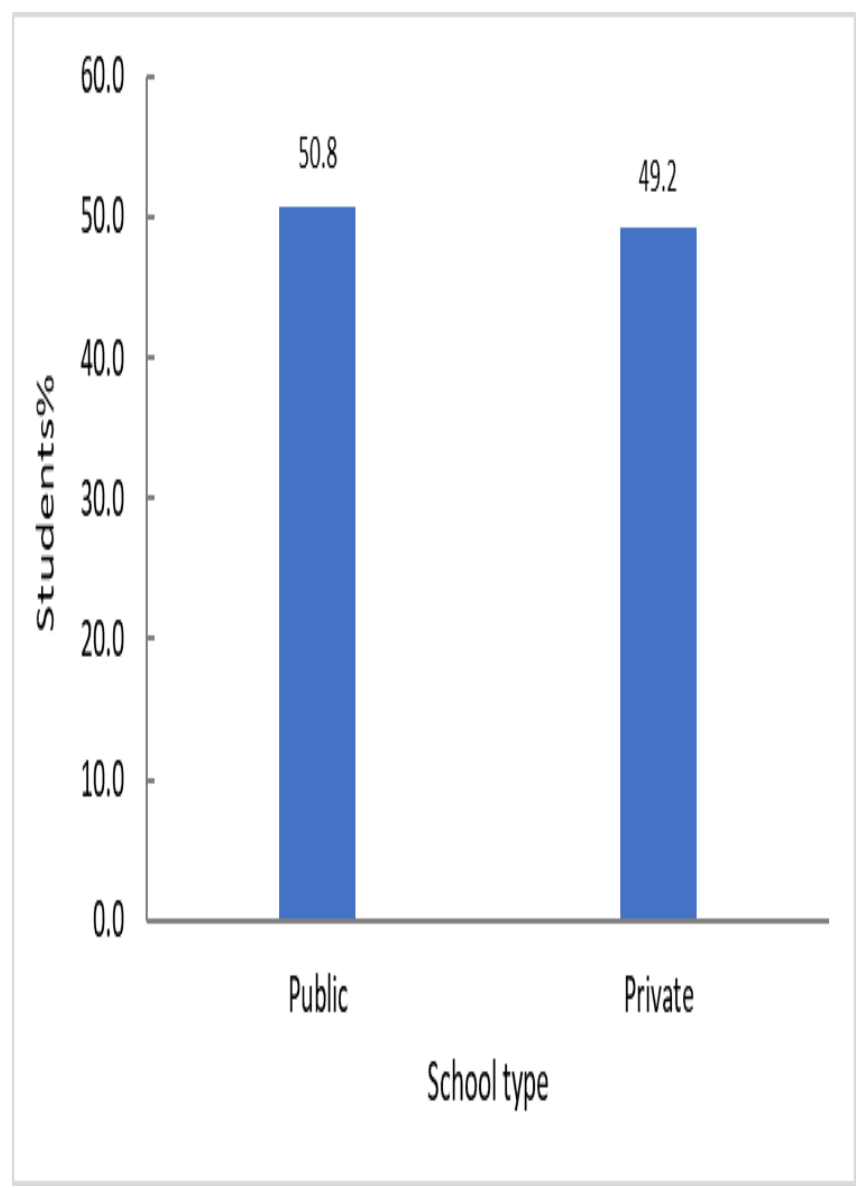

Figure 2. Distribution of the Turkish students in the public and private schools.

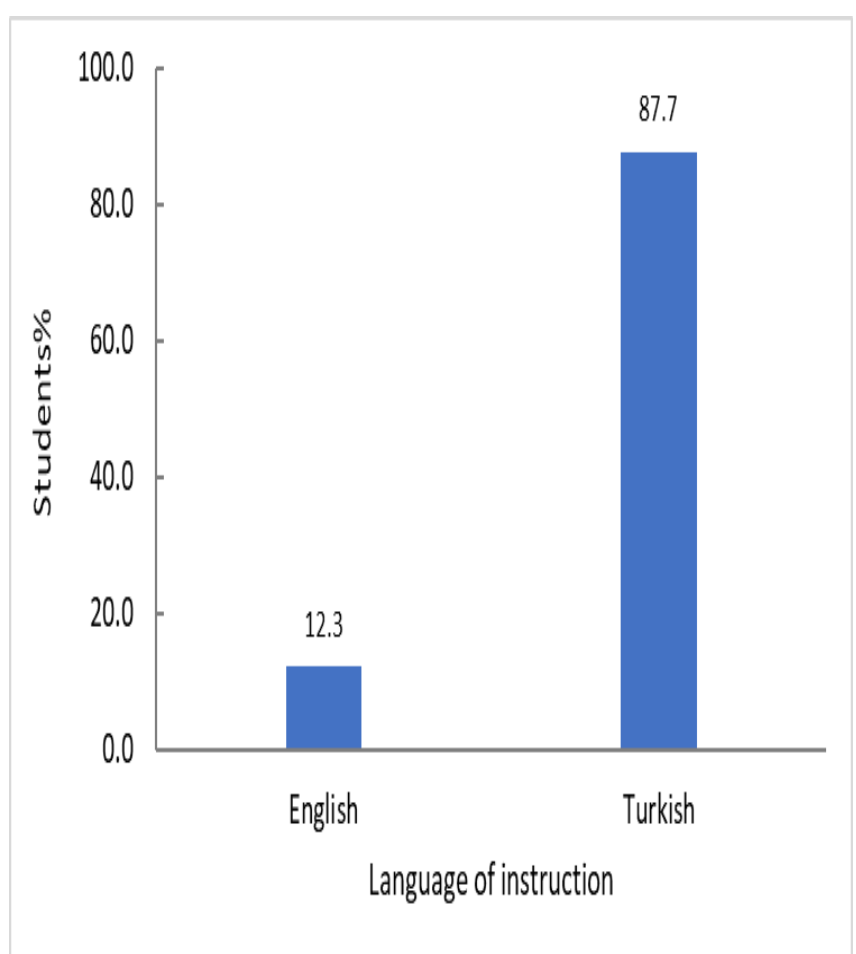

Figure 3. Language of instruction in the public and private schools.

The study shows that the majority of students started learning English at a young age, and a small 
percentage of them started in kindergarten $(10.8 \%)$, and the largest percentage was in elementary school (38.5\%), followed by preparatory $(27.7 \%)$, then high school $(16.9 \%)$, and a few at the university level $(6.15 \%)$ as shown in Figure 4. It should be noted that despite studying English language subject in public schools, students do not have a clear interest in it, so students graduate from high school and their information is almost superficial due to the lack of passion. Teaching English in public schools starts from the second grade of primary school as a compulsory subject, but its grade is not counted in the general average at the primary level, and it is sufficient to obtain a passing grade.

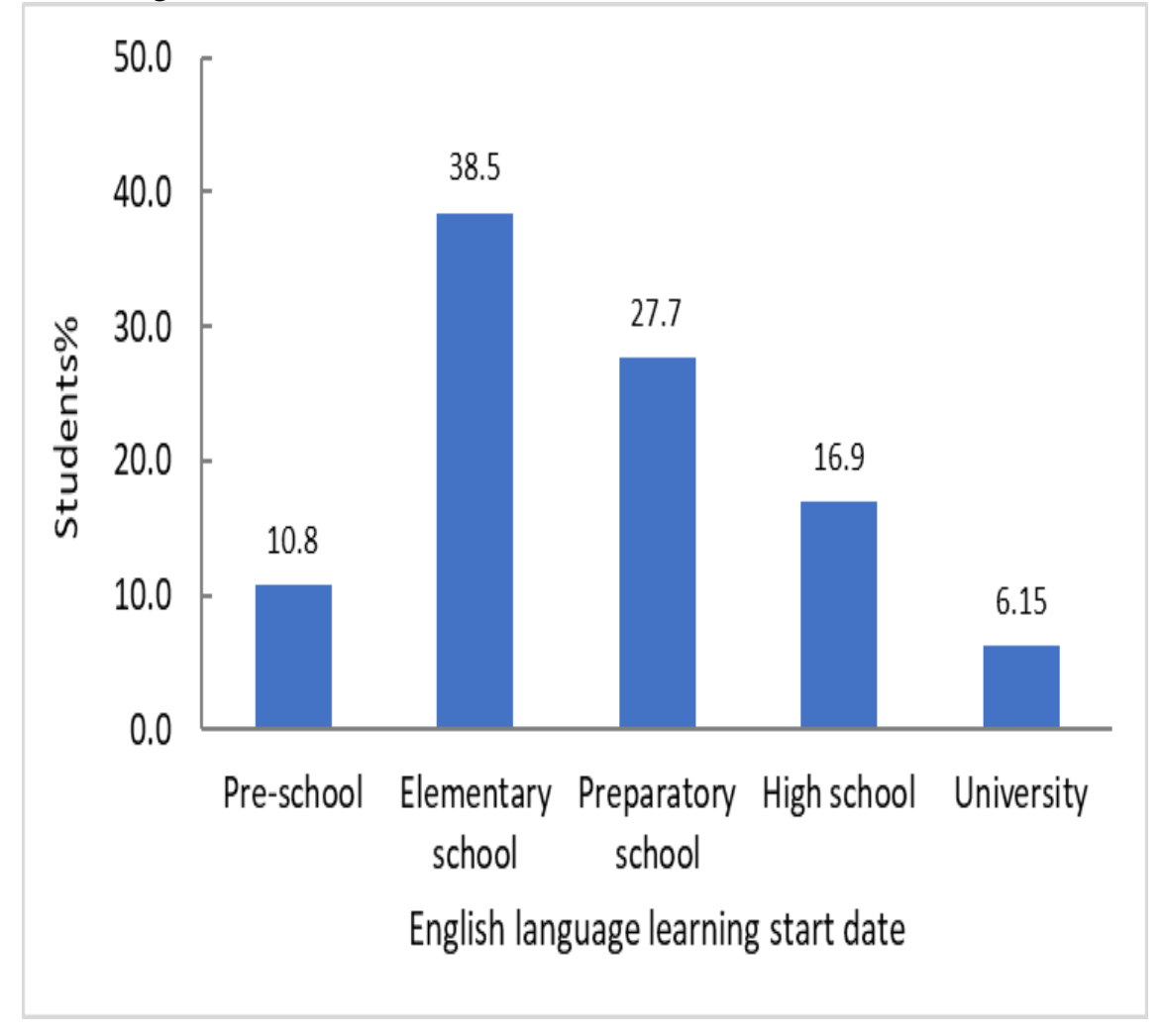

Figure 4. The start date of English language learning for the students of the sample.

notes in English during the lecture increases, so the majority of students $(48.6 \%)$ resort to take notes in

When students are asked about weaknesses in the English language, the results show that students suffer weakness in conversation $(43.4 \%)$, followed by grammar $(39.6 \%)$, then vocabulary $(36.4 \%)$, and to a lesser degree, listening $(36.0 \%)$ and a small percentage (23.0\%) suffer from poor reading skill. This weakness in the English language is in turn reflected in learning chemistry in the English language. For example, if the student suffers from a weakness in listening, he will suffer from the same problem in chemistry lectures, and this applies to the rest of the language skills. It is noted from the results that an average percentage of students (42.8\%) had difficulty understanding chemistry in the Turkish language, but this percentage increase significantly $(52.6 \%)$ when moving to university and studying chemistry in English.

To determine the reasons for the difficulty of learning chemistry in English, the results showed that nearly half of the students $(56.4 \%)$ suffer from difficulties listening to the lecture in English and the percentage of students (65.0\%) who suffer from taking Turkish. The reason may be a weakness in the students' ability to write as well as their fear of not being able to follow up with the teacher if they continue taking down notes in English, so they resort to taking notes in their native language. The students were asked about the difficulty in understanding chemical subjects in the English language, as the results showed that more than half of the students $(59.6 \%)$ had difficulty understanding chemical concepts and terms, so the majority of students believed $(45.6 \%)$ that the situation would be better if the concepts and terms were written in English alongside Turkish in textbooks. In comparison to concepts and terminology, the same percentage of students $(59.6 \%)$ have difficulty writing symbols and chemical formulas for elements and compounds

The reason for this decrease may be due to the convergence of the names of some elements and compounds in the Turkish and English languages. The 
percentage of students who have difficulty in chemical calculations $(51.0 \%)$ is slightly decreased may be due to the fact that students do not need much English in mathematics. Although students face difficulty in chemistry, a large percentage $(65.8 \%)$ of them do not agree that chemistry in general is not enjoyable, and the majority of students $(72.4 \%)$ do not blame the difficulty of chemistry on the subject teacher, which indicates that the main reason for the difficulties faced bystudents go back to their weakness in the English language.

The study showed the reflection of the weakness of students in English in general on the degree of students' participation during the lecture, as the results showed that a large percentage of students $(69.8 \%)$ hesitate to participate in the lecture because of the English language. In the same connection results also showed a large percentage of students $(70.4 \%)$ hesitate if they were asked to deliver apresentation on chemistry in English. To make sure that the reason for students not participating is the weakness of the English language, we asked the students if there are any other reasons for not participating, such as shyness, for example. Students (54.4\%) explained that the reasons are mainly due to their poor English language. This also confirms that a large percentage of students (58.2\%) feel anxious and embarrassed for fear of making mistakes if they participate in the English language.

The study shows that despite the difficulties that students face to study chemistry in the English language, the majority of students (74.2\%) feel satisfied with their choice of university study in English, and the reason may be because studying in English opens up other work opportunities for them and increases the diversity of resources that the student can make use of, unlike specialization in Turkish, where the resources available to the student are only in Turkish, unless the student has a good level of English. The student's abilities in the English language can be improved by encouraging the student to participate more through utilizing various eclectic educational methods. The results showed that $51.0 \%$ of students are motivated to learn the English language, as the majority of students $(85.6 \%)$ believe that more attention should be given to improving the ability to communicate verbally. Also, most students (69.6\%) think that they need more activities to encourage them to participate during the lecture. Most students also believe $(85.8 \%)$ the importance of the lecture environment, where the quiet environment provides an opportunity for the student to listen well, especially for students who suffer from a problem in listening skill.

The results show the effect of students' level in the English language on the degree of their comprehension and understanding of chemistry although the English language alone is not sufficient to fully comprehend the subject of chemistry. There are some difficulties related to thestruggle students face to digest the material itself due to the large number of abstract concepts in chemistry. The studyhas been conducted with the aim of improving the students' degree of comprehension. Several solutions have been proposed, including the use of various educational methods.In the next section we will look at the communication related teaching methods that can be used to improve the level of students in English and therefore reflect this on improving their learning abilities in chemistry.

Table 1. Students' responses on agree/disagree questions $(\mathrm{n}=65)$.

\begin{tabular}{llllll}
\hline & $\begin{array}{l}\text { Strongly } \\
\text { disagree }\end{array}$ & Disagree & Neutral & Agree & Strongly agree \\
\hline Q1 & $18(27.7)$ & $29(44.6)$ & $11(16.9)$ & $5(7.70)$ & $2(3.10)$ \\
Q2 & $10(15.4)$ & $23(35.4)$ & $16(24.6)$ & $13(20.0)$ & $3(4.60)$ \\
Q3 & $8(12.3)$ & $23(35.4)$ & $10(15.4)$ & $21(32.3)$ & $3(4.60)$ \\
Q4 & $4(6.20)$ & $18(27.7)$ & $12(18.5)$ & $20(30.8)$ & $11(16.9)$ \\
Q6 & $8(12.3)$ & $16(24.6)$ & $12(18.5)$ & $27(41.5)$ & $2(3.10)$ \\
Q7 & $6(9.20)$ & $13(20.0)$ & $26(40.0)$ & $16(24.6)$ & $4(6.20)$ \\
Q8 & $10(15.4)$ & $29(44.6)$ & $10(15.4)$ & $12(18.5)$ & $4(6.20)$ \\
Q9 & $4(6.20)$ & $13(20.0)$ & $18(27.7)$ & $7(10.8)$ & $23(35.4)$ \\
Q10 & $2(3.10)$ & $15(23.1)$ & $14(21.5)$ & $15(23.1)$ & $19(29.2)$
\end{tabular}




\begin{tabular}{llllll} 
Q12 & $10(15.4)$ & $39(60.0)$ & $5(7.70)$ & $10(15.4)$ & $1(1.50)$ \\
Q13 & $43(66.2)$ & $19(29.2)$ & $3(4.60)$ & $0(0.0)$ & $0(0.0)$ \\
Q14 & $2(3.10)$ & $2(3.10)$ & $24(36.9)$ & $22(33.8)$ & $15(23.1)$ \\
Q15 & $6(9.20)$ & $8(12.3)$ & $11(16.9)$ & $16(24.6)$ & $24(36.9)$ \\
Q16 & $0(0.0)$ & $5(7.70)$ & $30(46.2)$ & $27(41.5)$ & $3(4.60)$ \\
Q17 & $14(21.5)$ & $28(43.1)$ & $16(24.6)$ & $5(7.70)$ & $2(3.10)$ \\
Q23 & $28(43.1)$ & $30(46.2)$ & $5(7.70)$ & $2(3.10)$ & $0(0.0)$ \\
Q24 & $8(12.3)$ & $19(29.2)$ & $13(20.0)$ & $21(32.3)$ & $4(6.20)$ \\
Q25 & $13(20.0)$ & $25(38.5)$ & $13(20.0)$ & $13(20.0)$ & $1(1.50)$ \\
Q26 & $2(3.10)$ & $0(0.0)$ & $4(6.20)$ & $31(47.7)$ & $28(43.1)$ \\
Q27 & $2(3.10)$ & $2(3.10)$ & $30(46.2)$ & $25(38.5)$ & $6(9.20)$ \\
Q28 & $0(0.0)$ & $1(1.50)$ & $2(3.10)$ & $39(60.0)$ & $23(35.4)$ \\
\hline
\end{tabular}

Table 2. Students' responses on always/never question $(\mathrm{n}=65)$.

\begin{tabular}{llllll}
\hline & Always & Usually & Sometimes & Rarely & Never \\
\hline Q5 & $15(23.1)$ & $26(40.0)$ & $10(15.4)$ & $9(13.8)$ & $5(7.7)$ \\
Q11 & $22(33.8)$ & $23(35.4)$ & $18(27.7)$ & $2(3.10)$ & $0(0.0)$ \\
\hline
\end{tabular}

Table 3. Students' responses on very difficult/none questions $(n=65)$.

\begin{tabular}{llllll}
\hline & $\begin{array}{l}\text { Very } \\
\text { Difficult }\end{array}$ & Difficult & Moderate & Little & None \\
\hline Q18 & $0(0.0)$ & $6(9.20)$ & $43(66.2)$ & $14(21.5)$ & $2(3.10)$ \\
Q19 & $4(6.20)$ & $13(20.0)$ & $32(49.2)$ & $10(15.4)$ & $6(9.20)$ \\
Q20 & $7(10.8)$ & $14(21.5)$ & $30(46.2)$ & $11(16.9)$ & $3(4.60)$ \\
Q21 & $1(1.50)$ & $11(16.9)$ & $35(53.8)$ & $10(15.4)$ & $8(12.3)$ \\
Q22 & $0(0.0)$ & $4(6.20)$ & $21(32.3)$ & $21(32.3)$ & $19(29.2)$ \\
\hline
\end{tabular}

Table 4. Mean and standard deviation of Students' responses on the Questionnaire $(n=65)$.

\begin{tabular}{lll}
\hline Question & Mean & SD \\
\hline What type of school did you graduate from? & \\
\hline $\begin{array}{l}\text { What was the language of instruction of chemistry at } \\
\text { school? }\end{array}$ & \\
\hline At what stage did you start learning English?
\end{tabular}




\begin{tabular}{|c|c|c|c|}
\hline Q1 & $\begin{array}{l}\text { Did you usually have difficulty in understanding } \\
\text { chemistry at high school? }\end{array}$ & 2.14 & 1.01 \\
\hline Q2 & $\begin{array}{l}\text { Do you generally find it difficult to understand a } \\
\text { chemistry lecture in English? }\end{array}$ & 2.63 & 1.10 \\
\hline Q3 & $\begin{array}{l}\text { Do you find it difficult to listen with understanding } \\
\text { during a chemistry lecture in English? }\end{array}$ & 2.82 & 1.15 \\
\hline Q4 & $\begin{array}{l}\text { Do you find it difficult to write notes in English during } \\
\text { a chemistry lecture? }\end{array}$ & 3.25 & 1.20 \\
\hline Q5 & $\begin{array}{l}\text { Do you take notes during the lecture in your native } \\
\text { language? }\end{array}$ & 2.43 & 1.20 \\
\hline Q6 & $\begin{array}{l}\text { Do you find it difficult to understand the chemical } \\
\text { terms and concepts in English? }\end{array}$ & 2.98 & 1.13 \\
\hline Q7 & $\begin{array}{l}\text { Do you find it difficult to write the names of chemical } \\
\text { elements and compounds in English? }\end{array}$ & 2.98 & 1.03 \\
\hline Q8 & $\begin{array}{l}\text { Do you find it difficult to do chemical calculations in } \\
\text { English? }\end{array}$ & 2.55 & 1.14 \\
\hline Q9 & $\begin{array}{l}\text { Do you hesitate to participate in discussions during the } \\
\text { lecture because of your English? }\end{array}$ & 3.49 & 1.31 \\
\hline Q10 & $\begin{array}{l}\text { If you were asked to give a presentation on chemistry in } \\
\text { English, would you find it difficult to deliver? }\end{array}$ & 3.52 & 1.22 \\
\hline Q11 & $\begin{array}{l}\text { If you find it difficult to understand a certain topic, do } \\
\text { you use resources in your native language to understand } \\
\text { these topics? }\end{array}$ & 2.00 & 0.86 \\
\hline Q12 & $\begin{array}{l}\text { Do you have other reasons for not participating in class } \\
\text { discussions other than poor language, such as shyness, } \\
\text { for example? }\end{array}$ & 2.28 & 0.95 \\
\hline Q13 & $\begin{array}{l}\text { Do you blame the teacher for not understanding } \\
\text { chemistry in English? }\end{array}$ & 1.38 & 0.57 \\
\hline Q14 & $\begin{array}{l}\text { Do you feel satisfied with your choice to study in } \\
\text { English at university? }\end{array}$ & 3.71 & 0.96 \\
\hline Q15 & $\begin{array}{l}\text { Do you think you could get higher grades if you studied } \\
\text { chemistry in Turkish? }\end{array}$ & 3.68 & 1.33 \\
\hline Q16 & $\begin{array}{l}\text { Do you think teaching aids help you to understand } \\
\text { chemistry in English? }\end{array}$ & 3.43 & 0.70 \\
\hline Q17 & $\begin{array}{l}\text { If chemical terms were written in English alongside } \\
\text { Turkish at school, do you think this procedure could } \\
\text { have improved your understanding of chemistry in } \\
\text { English at the university? }\end{array}$ & 2.28 & 0.98 \\
\hline Q18 & Determine your degree of difficulty in words? & 3.18 & 0.63 \\
\hline Q19 & Determine your degree of difficulty in grammar? & 3.02 & 0.98 \\
\hline Q20 & Determine your degree of difficulty in conversation? & 2.83 & 0.99 \\
\hline Q21 & Determine your degree of difficulty in listening? & 3.20 & 0.91 \\
\hline Q22 & Determine your degree of difficulty in reading? & 3.85 & 0.92 \\
\hline Q23 & Do you think chemistry materials are uninteresting? & 1.71 & 0.74 \\
\hline Q24 & $\begin{array}{l}\text { Do you think you are anxious to make mistakes and } \\
\text { lose face? }\end{array}$ & 2.91 & 1.16 \\
\hline Q25 & $\begin{array}{l}\text { Do you think you lack the motivation to learn English } \\
\text { well? }\end{array}$ & 2.45 & 1.07 \\
\hline Q26 & $\begin{array}{l}\text { Do you think a lot of attention should be paid to } \\
\text { improving oral communicative competence? }\end{array}$ & 4.28 & 0.83 \\
\hline Q27 & $\begin{array}{l}\text { Do you think you need more communicative activities } \\
\text { in classroom teaching? }\end{array}$ & 3.48 & 082 \\
\hline
\end{tabular}




\begin{tabular}{c}
\hline Q28 $\begin{array}{l}\text { Do you think the relaxed classroom atmosphere is } \\
\text { important for English speaking practice? }\end{array}$ \\
\hline Response scale: 1 = Strongly Disagree; 2 = Disagree; $3=$ Neutral; $4=$ Agree and $5=$ Strongly Agree. \\
Response scale: $1=$ Very Difficult; $2=$ Difficult; $3=$ Moderate; $4=$ Little and $5=$ None. \\
Response scale: $1=$ Never; $2=$ Rarely; $3=$ Sometimes; $4=$ Usually and $5=$ Always.
\end{tabular}

\section{Classroom practices}

Literature is teemed with research on how to activate classroom practices to meet their optimal targets. The question is always how to get the best out of each classroom activity. The mechanism should create situations where students are encouraged to get involved and immersed in learning opportunities in which they not only show their best but also do their best[6]. Some of the most common methods and models include natural approach, content-based education, task-based education, collaborative learning, and communication education[1]. Nowadays, Developments in language studies have affected the teaching of language. One of the main developments in the current language is the concept of the communicative competency initiated by Hymes[21]. The communication proficiency is knowledge of the language (e.g., sound system and structures) and the social context of the use of the language. Knowing the rules of language is not enough to help one communicate with others in different situations. One must also know the situational context, the who, the where, and the when of the interaction[22].

The communication approach, an application of the communication proficiency, emphasizes language instruction which is based on classroom interactivities and group interaction. Research has shown that high intellectual tasks have been successfully completed by people who have interacted with others about what they were doing as they were progressing. Many English as a foreign language (EFL) researchers think that interaction with peers and groups of students facilitate problem solving situations as these classroom activities are anxiety free and enhance the learnability of students. In short, communicative tasks provide an opportunity for meaningful interaction, thereby creating an appropriate learning situation[22, 23].

Syllabus and teaching materials Learning goals of the Communicative Approach

The primary goal of communication approach is to enable foreign language learners to communicate efficiently in foreign language. In other words, the learner must be able to understand what others are saying and writing, and must be able to fluently express themselves when speaking and writing to others in different situations. The communication approach highlights all language skills - listening, speaking, reading and writing.
The communication approach adopts classroom activities that encourage group work and collaboration among class members. This means a different role for the learner from the traditional role of simply repeating or doing some sentence-based exercise. The learner is the focal point and acts as a collaborative element that collaborates with other members of their group to perform teacher-provided communication exercises. Moreover, the pair and group interactions provide appropriate opportunities for students to engage in problem0solving situations and experience the fourintegrated language skills (listening, speaking, reading and writing).

It shouldn't go without saying that teacher talking time (TTT) is minimal in comparison to student talking time (STT)[5]. More confirmingly, the teacher has a crucial role to play that is of the facilitator. The role of facilitator entails organizing resources to facilitate classroom communication whether this communication process occurs between learners themselves or between learners and the tasks they work with. This role also refers to the teacher's role as an assessor trying to assess learners' results. The teacher participates in the classroom interaction as a participant. He must be able to distance himself from the interaction in order to monitor it. The teacher guides and helps his/her students/learners complete the tasks without giving them the right solution to make them work on their own. Teachers must create a friendly atmosphere in class to motivate their students and help them build confidence in themselves. Good harmony will help learners relax. As mentioned earlier, the main objective of the communicative approach is to enable students to communicate effectively using foreign language. We also stated that this goal requires alternative types of teaching and learning activities other than the traditional position of a teacher facing learners in addressing issues that may not be true for them in terms of communication. These various activities turn classroom interactions social routines based mainly on communicative tasks among students. The next section will deal with the Comprehensible Input of Krashen which consolidates the concept of communicative approach.

The comprehensibleinput

It is recommended to discuss the natural approach which is based on Krashen's theory of second language learning as it offers a way out for enhancing language skills, accelerate and consolidate language productive skills. Stephen Krashen has left his impact 
on the field of EFL/ESL. He commenced writing about the comprehensible input two decades ago but till date his input has always been a point of discussion among educators[24]. Krashen introduced a comprehensive second language acquisition theory with a curriculum for language classrooms[24]. Lewis, on the other hand, embraced the Natural Approach which has influenced to a great extent ESL/EFL genres and related textbooks and the literature which dealt with teacher development $[25,26]$. The very exact terms defining the pedagogical factors affecting first and second language development in Krashen's Monitor Model have been used in some teacher assessment tests[27]. Learners have an affective filter that influences how much learning can take place; students who have high learner anxiety, low self-confidence, and low motivation are said to have high affective filters that can prevent them from learning[28]. English learning requires comprehensible input -- meaningful input based on real communication that is immediately comprehensible to the language learner[28]. In the same vein, Lightbown and Spada have proved that 'comprehensible input' contributes to learners' progress[29]. Krashen hols the opinion that reading is more important to learning how to write well than writing practice is. More reading practices should be given more space in out syllabuses[30].

Krashen's fivehypotheses

Krashen's theory explored the process of acquisition of first and second language by means of comparison. $\mathrm{He}$ has mentioned five hypotheses: The natural order hypothesis, The Acquisition/ Learning Hypothesis, the Monitor Hypothesis, the Input Hypothesis, and Affective Filter Hypothesis[31]. In order to serve the purposes of the current study we are going to elaborate more on The Input Hypothesis. This hypothesis also supports the fact that pronunciation of the first second language of adult learners is very similar to those of infants in their first language. However, it is the results of methods such as universal physical response to evil that provide the most convincing evidence. This method has proved to be much better than language, grammar, or other techniques.

The inputhypothesis

The input hypothesis states that humans acquire language in only one way - by understanding messages or by receiving "comprehensible input". Here, Krashen claims that successful "acquisition" occurs simply by understanding inputs that slightly exceed the current "level" of the learner - he has identified the progress of "level" as $\mathrm{i}$ and the ideal level input as $\mathrm{i}+1$ [32].
It is apparent that the best syllabus educators can provide students is the syllabus students can understand. The more students are exposed to chunks of language they understand they will be more involved in meaningful communication and there will be no need to worry about speaking as speaking will emerge by time.

Recommendation

In addition to the aforementioned, the most important recommendations that we believe can reduce students' struggle with learning chemistry in English can be summarized as follows:

The English language proficiency exam must include some questions from scientific disciplines to urge students to memorize scientific terms before entering the exam and joining the university, as well as that the training course to prepare for the English language exam includes a course for teaching scientific terminology and some concepts for each student according to his scientific specialization in which he will enroll at the university. It is also preferable to involve the student in discussions during the lecture with the use of the compliment method as well as increasing the number of assignments and reports to improve their writing abilities. As well as encouraging students to join the English language clubs at the university and establishing a special club in the department under the supervision of the students themselves to exchange experiences and improve their capabilities. Also, the teacher's role is important in providing an attractive and encouraging learning environment and avoiding embarrassing comments or expressions for the student, which may lead to an adverse effect that affects the student's psyche and his ability to participate in discussions in the future and also negatively affects his ability to pay attention and focus.

As a result of implementing the Natural Approach in teaching we can help language production begin naturally. It would be observed that acquisition activities are central with some monitoring somehow somewhere. However, we need to deal with low selfesteem to help learners transfer to high achievers. Classroom techniques include dialogues - short and useful - 'open' dialogues interviews - pair work on personal information personal charts and tables preference ranking - opinion polls on favorite activities etc. revealing information about yourself e.g. what I had for breakfast activating the imagination - e.g. give colleagues advice about their healthy dietitian. Problem-solving activities should be implemented to help natural acquisition and they may include developing speech for particular occasions - 
e.g. what do you say if...? Learning activities can be introduced, and they are experiences you design, that enable students to more deeply understand a topic. The best activities are ones where students are active - e.g. where they are sharing, discussing, creating, constructing, reflecting, applying. Watching videos, reading written content, listening to podcasts and reading articles (which we covered in Content and Resources) are also forms of activity, but they are more on the passive end. Deep learning happens with activities where the students are active and doing.

\section{Conclusion}

Chemistry is proven to be one of the most difficult subjects for students around the world. Students face greater difficulties when moving to the university stage because of the great progress in subject level compared to that of school. In Turkey, some universities offercertain majors such as chemistry to be taught in the English language and here liethe difficulties students come across in learning. In this study, the difficulties faced by these students during their studies of chemistry in the English languagewere evaluated. The results showed that the students' level in the English language plays a vital role as to the degree of their comprehension and understanding of chemistry.Vice versa, the poor level of the English language negatively affected the percentage of students' comprehension and participation in discussions during the lecture. A large proportion of them (48.6\%) resorted to taking notes in Turkish during the lecture and a large proportion of the students (45.6\%) believed the use of English terminology alongside Turkish in textbooks will positively affect students' abilities. The study recommends diversity in teaching methods and the implementation of the Communicative and Natural Approach to deal with communication difficulties in chemistry classes.

Funding: This research received no external funding. Conflicts of Interest: The authors declare no competing interests.

\section{References}

1. Westwood, P.S., What teachers need to know about teaching methods. 2008, Australia: Aust Council for Ed Research.

2. Petrina, S., Advanced teaching methods for the technology classroom. 2006: IGI Global.

3. Balan, P. and M. Metcalfe, Identifying teaching methods that engage entrepreneurship students. Education + Training, 2012. 54(5): p. 368-384.
4. Ricca, B., Beyond teaching methods: A complexity approach. Complicity: An International Journal of Complexity and Education, 2012. 9(2).

5. Alozie, N. and C. Mitchell, Getting students talking: Supporting classroom discussion practices in inquiry-based science in real-time teaching. The american biology Teacher, 2014. 76(8): p. 501-506.

6. McCroskey, J.C. and V.P. Richmond, Power in the classroom I: Teacher and student perceptions. Communication Education, 1983. 32(2): p. 175184.

7. Frymier, A.B. and M.L. Houser, The teacher-student relationship as an interpersonal relationship. Communication education, 2000. 49(3): p. 207-219.

8. Dobransky, N.D. and A.B. Frymier, Developing teacher-student relationships through out of class communication. Communication Quarterly, 2004. 52(3): p. 211-223.

9. Kumar, C.P., The eclectic method-theory and its application to the learning of English. International Journal of Scientific and Research Publications, 2013. 3(6): p. 1-4.

10. James, M., Assessment, teaching and theories of learning.

11. Sirhan, G., Learning difficulties in chemistry: An overview. 2007.

12. Carter, C.S. and N.W. Brickhouse, What makes chemistry difficult? Alternate perceptions. Journal of Chemical Education, 1989. 66(3): p. 223.

13. Osman, K. and N.S. Sukor, Conceptual understanding in secondary school chemistry: A discussion of the difficulties Experienced by students. American Journal of Applied Sciences, 2013. 10(5): p. 433.

14. Gabel, D., Improving teaching and learning through chemistry education research: A look to the future. Journal of Chemical education, 1999. 76(4): p. 548.

15. Woldeamanuel, M.M., H. Atagana, and T. Engida, What makes chemistry difficult? African Journal of Chemical Education, 2014. 4(2): p. 3143.

16. O'Dwyer, A. and P.E. Childs, Who says organic chemistry is difficult? Exploring perspectives and perceptions. EURASIA Journal of Mathematics, Science and Technology Education, 2017. 13(7): p. 3599-3620.

17. Brown, M.R., K. Higgins, and K. Paulsen, Adolescent alienation: What is it and what can educators do about it? Intervention in School and Clinic, 2003. 39(1): p. 3-9. 
18. Mann, S.J., Alternative perspectives on the student experience: Alienation and engagement. Studies in higher education, 2001. 26(1): p. 7-19.

19. Study in Turkey. 2020 [cited 2020 December 25, 2020]; Available from: https://www.studyinturkey.gov.tr/.

20. Announced education statistics in Turkey (Türkiye'nin eğitim öğretim istatistikleri açıkland1), in Hurriyet. 2020: Turkey.

21. Hymes, D.H., Pidginization and creolization of languages. 1971: CUP Archive.

22. Krashen, S. and C.L. Brown, What is academic language proficiency. STETS Language \& Communication Review, 2007. 6(1): p. 1-5.

23. Bialystok, E., Analysis and control in the development of second language proficiency. Studies in second language acquisition, 1994: p. 157-168.

24. Krashen, S.D. and T.D. Terrell, The natural approach: Language acquisition in the classroom. 1983.
25. Lewis, M., et al., Implementing the lexical approach: Putting theory into practice. Vol. 3. 1997: Language Teaching Publications Hove.

26. Lewis, M. The Lexical Approach: The State of ELT and a Way Forward. 2002.

27. Veneman, J., et al., California Commission on Teacher Credentialing. 1998.

28. Krashen, S.D., Language acquisition and language education: Extensions and applications. 1989: Prentice Hall International New York.

29. Lightbown, M. and N. Spada, How Languages are Learnt: Oxford University Press. 2006.

30. Krashen, S.D., The Power of Reading: Insights from the Research. 2004: Libraries Unlimited.

31. Zafar, M., Monitoring the'monitor': A critique of Krashen's five hypotheses. Dhaka University Journal of Linguistics, 2009. 2(4): p. 139-146.

32. Krashen, S.D., The input hypothesis: Issues and implications. 1985: Addison-Wesley Longman Ltd. 